\title{
Impact of Water Stress on Growth, Productivity and Powdery Mildew Disease of Ten Sugar beet Varieties
}

\author{
Farrag F.B. Abu-Ellail* and Mohamed M. A. El-Mansoub $^{1}$
}

\begin{abstract}
Powdery mildew is a fungal disease that causes a serious reduction in both root and sugar yields in sugar beet areas in Egypt. This study aimed to determine the effect of three water stress treatments namely, $I_{1}$ (recommended irrigation times), $I_{2}$ (3 withholding irrigation times), and $\mathrm{IR}_{3}$ (4withholding irrigation times) on powdery mildew infection severity and yield components of ten sugar beet varieties. The experimental design was a split-plot design with three replications at Al-Fayoum Governorate, $\left(29^{\circ} 17^{`} \mathrm{~N} ; 3^{\circ} 53\right.$ ' E), Egypt, during 2017/2018 and 2018/2019 growing seasons. Results showed that disease severity varied significantly under the three water stress treatments, which were about 21.02, 18.71, and $16.60 \%$, respectively. Meanwhile, $\operatorname{IR}_{3}$ (4 withholding irrigation times) is more effective in the control of powdery mildew disease, but it is the lowest one in yield components traits. Varieties i.e. Heba, Pleno, Beta 382 and Sibel registered the lowest values of disease severity percentage $(11.77,13.64,14.90$, and $16.40 \%$, respectively). Withholding of irrigation had a significant effect $(P<0.05)$ on sugar and root yields so that $I_{3}$ water stress treatment registered lower yield (2.78 and 18.53 ton/fed) than $I_{2}$ water stress treatment (3.17 and 22.60 ton/fed). As a result, growing sugar beet under $I_{2}$ water stress produced higher sugar content and less amino- $\mathrm{N}$ and $\mathrm{Na}$ accumulation in the root, as compared to $I_{2}$ water stress. The lowest disease severity percentage $(11.77 \%)$ along with the best root yield (22.20 ton/fed) was observed in Heba variety. Sugar beet varieties i.e. Heba, Beta382, and Sibel registered the highest value of oxidative enzymes (catalase, peroxidase, polyphenol oxidase), and we can be recommended these as tolerant disease varieties. Skipping one or more irrigation to reduce the powdery mildew disease was recommended. According to the results, the stress tolerance index (STI) and of geometric mean productivity (GMP) appears to be a suitable selection index to distinguish tolerant sugar beet varieties for water stress.
\end{abstract}

DOI: $10.21608 / A S E J A I Q J S A E .2020 .91325$

${ }^{1}$ Sugar Crops Research Institute, Agricultural Research Center,

Giza 12619, Egypt.

*Corresponding author: farrag_abuellail@yahoo.com

Received April 5, 2020, Accepted, May 17, 2020.
Breeders should focus on the performance of varieties with high root yield in diverse environments and high extractable sugar.

Keywords: Sugar beet, powdery mildew, disease severity, water stress, stress tolerance index.

\section{INTRODUCTION}

Sugar beet (Beta vulgaris L.) is considered as one of the two important sugar crops worldwide. Total sugar beet cultivated area reached 208.33 thousand hectares in Egypt. Recently sugar beet surpassed sugar cane in sugar productivity and became the first source of sugar production in Egypt compared to sugar cane. Sugar beet is suffering from infection with many important plant diseases in various stages of development. Fungal diseases are the most important diseases that affect beet in terms of economic importance and spread.

Powdery mildew is considered one of the most dangerous fungal diseases affecting sugar beet in several sugar beet growing countries. Powdery mildew caused by Erysiphe betae (Vanha) is a serious fungal foliar disease resulting in sugar yield losses of up to $30 \%$ and reduced the root yield by $20-25 \%$ and responsible for low production of sugar (Francis, 2002). In recent years, sugar beet powdery mildew disease began to spread in Egypt and became economically worthwhile. The disease appears first on lower and older leaves and gradually spreads towards the upper and younger leaves and infection is more common on upper surface of leaves than the lower ones (Srivastava, 2004), and caused declining rates of net photosynthesis as it directly affect the composition of sugar and other materials needed by the plant to supplement its life cycle (Hills et al., 1980). Disease damage varies in different regions, the disease spread and severity is largely dependent on weather condition in last winter and the summer of planting year (Draycott, 2006). Climatic elements affected a lot the growth and spread of this disease, as the incidence of this disease intensifies in humid weather, as humidity ranges from 30 to $50 \%$ accompanied by a moderate temperature (22 to $\left.32{ }^{\circ} \mathrm{C}\right)$. 
The relationship between water stress, powdery mildew, and productivity traits of sugar beet has been studied before. Most studies showed that water stress has a remarkable impact on disease control (Asher and Dewar, 2001). Irrigation regimes are more effective in controlling sugar beet powdery mildew disease (Basati et al., 2015). The timing, frequency, amount, and mode of irrigation may affect both yield and physiological traits responses (Abu-Ellail et al., 2016) and sensitivity to pathogenic agents (Pivonia et al., 2004), thus altering disease incidence and severity. As Rotem and Palti (1969) have suggested, irrigation influences disease development not only via an impact on conditions that favor host infection but also in terms of pathogen sporulation and subsequent spore dispersal. Flooding irrigation may increase the risk of foliar diseases compared to water stress.

Water stress is a major limiting factor that affects crop productivity in semi-arid regions. Because the quantity and distribution of rainfall are unpredictable in most arid regions, crop varieties must be produced under a wide range of moisture conditions. Drought tolerance should be considered an essential breeding objective in areas where the sugar beet crop is likely to encounter a water deficit (Sadeghian et al., 1999). Varieties with high productivity in both stress and nonstress conditions are useful for breeding purposes. Indicators of stress tolerance are useful in choosing adapted varieties like the drought sensitivity index (DSI), geometric mean productivity (GMP) and the stress tolerance index (STI) for screening drought tolerant genotypes in stress and non-stress conditions. (Hesadi et al., 2015, Sadeghian et al., 2000, and Mohamdian, 2010). The aims of this study were to evaluate the effect of water stress on yield, quality, and control of powdery mildew disease of ten sugar beet varieties, as well as to determine the efficiency of tolerance indices to identify drought-tolerant sugar beet varieties.

\section{MATERIALS AND METHODS}

The experiments were carried out at Al-Fayoum Governorate, $\left(29^{\circ} 17^{`} \mathrm{~N} ; 30^{\circ} 53^{`} \mathrm{E}\right)$, Egypt, to study the effect of three water stress treatments namely, $\mathrm{IR}_{1}$ (recommended irrigation times), $\mathrm{IR}_{2}$ ( 3 withholding irrigation times), and $\mathrm{IR}_{3}$ (4 withholding irrigation times) (Table 1) on powdery mildew disease of ten sugar beet varieties during the two successive growing seasons 2017-2018 and 2018-2019. This study was conducted under heavily natural infection conditions with powdery mildew disease. The fertilizers and all other agronomic practices were applied as recommended by the Ministry of Agriculture and Land Reclamation, Egypt.

The surface soil sample taken from the experimental site at a depth of $(30-40 \mathrm{~cm})$ before planting to identify some physical and chemical properties of the experimental soil as shown in (Table 2). The present study was arranged in a split-plot design with three replications. The water stress treatments were allocated in main plots, separated from each other by 1 meter distance to prevent water leakage during water treatment, meanwhile, varieties were occupied the subplot was randomly distributed in the subplot. Each experimental basic unit included 5 rows, $60 \mathrm{~cm}$ apart, 5 $\mathrm{m}$ long, and $20 \mathrm{~cm}$ between plants, comprising an area of $15 \mathrm{~m}^{2}$. Experiments were sown on November $25^{\text {th }}$ and $21^{\text {th }}$ in the first and second seasons, respectively. Monthly weather data at Fayoum, Egypt as an average for the two growing seasons of study are presented in Table 3.

\section{Assessment of powdery mildew disease:}

When the severity of the disease reached its maximum, the recording was conducted to determine the extent of disease infection. For the determination of infection percentage and selection of healthy plants, the index suggested by Paulus et al., (2001) was used which is the latest index used for powdery mildew damage. Determination of disease assessment after four months from sowing, powdery mildew leaf spot was counted on 50 plants and disease severity was calculated according to the scale of Whitney et al., (1983). For each treatment in each replication, 100 leaves were recorded and the infection score was attributed.

Table 1. Water stress treatments followed in this experiment

\begin{tabular}{lccccccccc}
\hline Weeks & $\mathbf{4}$ w & $\mathbf{7 w}$ & $\mathbf{1 0} \mathbf{w}$ & $\mathbf{1 3} \mathbf{w}$ & $\mathbf{1 6} \mathbf{w}$ & $\mathbf{1 9} \mathbf{w}$ & $\mathbf{2 2} \mathbf{w}$ & $\mathbf{2 5} \mathbf{w}$ & $\mathbf{2 8} \mathbf{w}$ \\
\hline $\mathrm{IR}_{1}$ & + & + & + & + & + & + & + & + & + \\
$\mathrm{IR}_{2}$ & + & - & + & + & - & + & + & - & + \\
$\mathrm{IR}_{3}$ & + & - & + & - & + & - & + & - & + \\
\hline
\end{tabular}

$\mathrm{IR}_{1}=$ normal irrigation, $\mathrm{IR}_{2}=3$ withholding irrigation and $\mathrm{IR}_{3}=4$ withholding irrigation

$(-)=$ Skipping or withholding irrigation,$(+)=$ Irrigation 
Table 2. Chemical and physical properties of the experimental soil

\begin{tabular}{lccccc}
\hline & \multicolumn{2}{c}{ Mechanical analysis } & \multicolumn{3}{c}{ Chemical analysis } \\
\cline { 2 - 6 } Properties & $\mathbf{2 0 1 7 - 1 8}$ & $\mathbf{2 0 1 8 - 1 9}$ & Properties & $\mathbf{2 0 1 7 - 1 8}$ & $\mathbf{2 0 1 8 - 1 9}$ \\
\hline Sand \% & 21.9 & 23.6 & $\mathrm{Ca}^{++}$ & 9.8 & 11.34 \\
Silt \% & 39.9 & 29.9 & $\mathrm{Mg}^{++}$ & 5.55 & 5.64 \\
Clay \% & 38.2 & 46.5 & $\mathrm{Na}^{+}$ & 18.3 & 19.7 \\
\hline Soil texture & \multicolumn{2}{c}{ Silty clay } & $\mathrm{K}^{+}$ & 0.65 & 0.42 \\
\hline EC (dSm-1) & 1.43 & 1.71 & $\mathrm{HCO}_{3}{ }^{-}$ & 2.5 & 2.8 \\
Ph (1:2.5) & 7.31 & 7.29 & $\mathrm{Cl}^{-}$ & 26.1 & 29.2 \\
$*$ Sp\% & 70 & 60 & $\mathrm{SO}_{4}^{-}$ & 5.7 & 5.1 \\
\hline
\end{tabular}

*SP= Saturation percentage.

Table 3. Monthly temperature and relative humidity

\begin{tabular}{|c|c|c|c|c|c|c|}
\hline \multirow[t]{3}{*}{ Months } & \multicolumn{2}{|c|}{ Temperature $\mathrm{C}$} & \multirow{3}{*}{$\begin{array}{c}\text { Relative } \\
\text { Humidity \% }\end{array}$} & \multicolumn{2}{|c|}{ Temperature $\mathrm{C}$} & \multirow{3}{*}{$\begin{array}{c}\text { Relative } \\
\text { Humidity } \%\end{array}$} \\
\hline & Maximum & Minimum & & Maximum & Minimum & \\
\hline & \multicolumn{2}{|c|}{$2017-2018$} & & \multicolumn{2}{|c|}{ 2018-2019 } & \\
\hline Nov. & 25.96 & 12.84 & 47.93 & 23.95 & 10.29 & 46.59 \\
\hline Dec. & 21.49 & 9.90 & 43.54 & 20.40 & 6.60 & 52.82 \\
\hline Jan. & 17.68 & 4.72 & 50.01 & 18.46 & 4.75 & 53.31 \\
\hline Feb. & 20.32 & 5.16 & 44.35 & 24.29 & 9.94 & 37.47 \\
\hline Mar. & 26.85 & 13.17 & 34.58 & 25.20 & 14.20 & 44.00 \\
\hline Apr. & 31.10 & 13.40 & 35.00 & 29.00 & 11.80 & 36.21 \\
\hline May & 36.80 & 19.50 & 33.00 & 33.60 & 16.30 & 35.12 \\
\hline Mean & 25.74 & 11.56 & 41.20 & 24.99 & 10.55 & 43.65 \\
\hline
\end{tabular}

Source: Meteorological Department, Agricultural Research Center, Ministry of Agriculture.

Scale ranged from $0-5$, categories whereas $0=$ no mildew colonies observed $1=1-10 \%, 2=11-35 \%, 3=$ $36-65 \%, 4=65-90 \%$ and $5=91-100 \%$, respectively of matured leaf area covered by mildew and the average disease rating per treatment was calculated.

Disease severity $(\%)=$ $\left\{\sum\right.$ (rating no.) $\times($ no. leaves in rating category $\left.) \times(100)\right\}$

\section{(Total no. leaves) $\times$ (highest rating value)}

\section{Biochemical changes determination:}

This study was carried out to determine some biochemical changes associated with the different treatments. Thus, total chlorophyll content, phenolic compounds, as well as the activity of oxidative enzymes, were determined in the leaves of ten sugar beet plants collected randomly from the second row of each sub plot from each sugar beet variety grown under different water stress treatments as follow:

1. Total chlorophyll content of leaves: was measured as optical density (OD) using Chlorophyll meter Model (SPAD-502) according to Uddling et al., (2007).
2. Total phenolic compounds: was determined using UV/Vis. Spectrophotometer, Jenway England at wavelength $750 \mathrm{~nm}$ as described by Singleton et al.,(1999) determined England (Folin and Ciocalteau phenol reagent).

3. Activities of oxidative enzymes: Sample preparation: $0.5 \mathrm{~g}$ leaf was homogenized at $4{ }^{\circ} \mathrm{C}$ with a $2 \mathrm{ml}$ sodium phosphate buffer of $0.1 \mathrm{M}(\mathrm{pH}$ 6.5 ). The homogeneous material was centrifuged at $10,000 \mathrm{rpm}$ for $2 \mathrm{~min}$ and the supernatant is used as an enzyme source for plant defense enzymes estimation. Peroxidase activity (POD) was determined by measuring the oxidation of guaiacol in the presence of hydrogen peroxide into the water at $470 \mathrm{~nm}$ as described by Hammerschmidt et al., (1982). The activity was expressed as the increase in absorbance at $470 \mathrm{~nm}$ in $\mathrm{min}^{-1} \mathrm{mg}^{-1}$ of protein. Polyphenol oxidase (PPO) activity was measured as per the procedure given by Mayer et al., (1965). Oxidation of the substrate catechol to yellow color benzoquinone was measured at $495 \mathrm{~nm}$. The activity was expressed as a change in absorbance at $495 \mathrm{~nm}$ in $\mathrm{min}^{-1} \mathrm{mg}^{-1}$ of protein. Catalase (CAT) activity was measured as mentioned by (Maxweell and Bateman, 1967). Results were calculated taking control as 
$100 \%$ to find increase or decrease in activities of enzymes.

At harvest 210 days from planting, the three guarded central rows of each sub- plot per each variety under the three water stress treatments were harvested to estimate yield and its attributes, as well as the following growth traits were estimated from random five plants:

\section{Growth traits}

Root length $(\mathrm{cm})$, Root diameter $(\mathrm{cm})$, and Root fresh weight/plant $(\mathrm{kg})$.

\section{Productivity traits}

1. Root yield (ton/fed): Calculated from root weight of experimental unit then converted to ton/fed.

2. Top yield (ton/fed): calculated from top weight of experimental unit then converted to ton/fed.

3. Sugar yield (ton/fed): calculated according to the following equation: Sugar yield (ton/fed)= extractable sugar\% x root yield (ton/fed)/100

\section{Quality traits}

Quality traits were determined in Al-Fayoum sugar company laboratories.

1. Impurities of juice, ( $\mathrm{K}$ and $\mathrm{Na}$ ) and Alpha-amino-N concentrations were estimated according to Brown and Lilliand (1964)

2. Sucrose\% was estimated in fresh root samples using (Saccharometer) according to the method described by A.O.A.C. (2005).

3. Sucrose loss to molasses (SLM \%) was determined according to (Devillers, 1988).

4. Extractable Sugar $\%=$ Sucrose $\%-$ SLM $\%-0.6$ (Dexter et al., 1967).

\section{Statistical analysis}

Data collected from each season was statistically analyzed according to Gomez and Gomez (1984) by using SAS computer software package. The separate analysis of variance for different treatments and the combined analysis of variance for different characters were performed on plot mean basis. Revised L.S.D at $5 \%$ level was used to compare the means according to Waller and Duncan (1969). Three selection indices, drought susceptibility index (DSI), stress tolerance index (STI) and geometric mean productivity (GMP), were estimated for each variety based on root yield and sugar yield under stress (Ys) and non-stress (Yp) conditions. Drought resistance indices were calculated using the following equations:

$$
\operatorname{DSI}=\frac{1-\left(\frac{\mathbf{Y s}}{\mathbf{Y} \mathbf{p}}\right)}{\mathbf{1}-\left(\frac{\overline{\mathbf{Y}} \mathbf{Y}}{\mathbf{Y} \mathbf{p}}\right)} \text { (Fischer and Maurer, 1978) }
$$

$$
{ }^{(2)} \mathrm{STI}=\frac{\mathbf{Y} \mathbf{p} \times \mathbf{Y S}}{(\overline{\mathbf{Y}} \mathbf{p})^{2}}
$$

(3)

$$
G M P=\sqrt{Y p \times Y_{S}}
$$

(Fernandez,1993)

Where Ys is the yield of variety under stress, Yp the yield of variety under irrigated condition, $\overline{Y s}$ and $\overline{Y p}$ are the mean yields of all varieties under stress and nonstress conditions, respectively, and $1-\left(\bar{Y}_{S} / \bar{Y} p\right)$ is the stress intensity. The irrigated experiment was considered to be non-stress conditions in order to have a better estimation of the optimum environment.

\section{RESULTS AND DISCUSSION}

\section{Effect of water stress and varieties on powdery mildew disease:}

According to the climatic data of El-Fayoum district in Table (3), show that mean of relative humidity $\%$ for two growing seasons (2017-2018 and 2018-2019) is 41.20 and $43.65 \%$, respectively, as well as, the mean minimum and maximum temperatures for two growing seasons are (11.56 and $\left.25.74{ }^{\circ} \mathrm{C}\right)$ and (10.55 and $24.99^{\circ} \mathrm{C}$ ), respectively, therefore it is suitability to spread powdery mildew disease. Data in harmony with (Neher and Gallian, 2013) who reported that the optimal temperature range for infection and colony development is $\left(15^{\circ}-30^{\circ} \mathrm{C}\right)$, infection occurs when daily temperatures fluctuate by up to $\left(15^{\circ} \mathrm{C}\right)$ between daytime and nighttime and under conditions at a very low relative humidity (30-40\%), as well as, (Hills et al., 1980) found the disease score rate increased with increasing relative humidity up to $100 \%$, in fact, decreasing moisture in soil inhibited disease infection and colony development. In the conditions of the absence of control measures, the disease severity of powdery mildew increased (Gado, 2013), the control of disease is mainly achieved by applications of increased plant spacing, used tolerant sugar beet varieties, and avoid excess nitrogen and irrigation (Francis, 2002).

\section{Disease severity (\%):}

Results in Table (4) indicated that powdery mildew disease severity (DS \%) was significantly decreased with increasing water stress during the two successive seasons. Average disease severity was decreased to 18.71 and $16.60 \%$ by withholding ( 3 and 4 times of irrigation, respectively) compared with normal treatment $(21.02 \%)$. A significant difference in disease severity $\%$ was also observed among varieties. Heba $\mathrm{cv}$. recorded the lowest disease severity (11.77\%) followed by Pleno cv. (13.64\%) and Beta382 (14.90\%) 
compared to the other treated varieties. Otherwise, Oscarpoly cv. recorded the highest value of D.S \% $(25.66 \%)$. A significant difference $(\mathrm{P}<0.05)$ was also observed among varieties for the infection score. Concerning the evaluated sugar beet varieties, data indicated that powdery mildew disease severity\% was significantly varied among the ten sugar beet varieties in the two growing seasons. It could be noticed that varieties (Oscarpoly, Pyramide and Univers) were most sensitive in the two growing seasons. The significance of water stress $\times$ varieties interaction $(P<0.05)$ showed that cultivars did not have the uniform performance for disease severity\%. This result might be due to the gene make-up, which plays an important role in plant structure and morphology. These findings are in the same line with those reported by Pivonia et al., (2004) indicated that less frequent and reduced irrigation postponed the onset of plant collapse and lowered disease incidence.

\section{Total chlorophyll:}

Total chlorophyll in leaves decreased significantly by increasing water stress (Table 4). Meanwhile, the highest total chlorophyll was produced by using moderate stress compared with normal irrigation treatment. This might be due to increasing disease severity and reducing the photosynthetic area as well as toxicity from toxins produced by the powdery mildew which prompts the plant to produce new leaves to compensate this loss of leaves and thus lead to a shortage in root crop and sugar (Barry et al., 2000 and Gary et al., 2011). A significant difference $(\mathrm{P}<0.05)$ was also observed among varieties for the chlorophyll content. Resistant varieties (Heba, Pleno, Beta382 and Sibel ) showed low infection under an increased number of furrow irrigation the rate was lower than susceptible varieties (Oscarpoly, Univers and Pyramide) which were held less chlorophyll (49.18, 51.25 and 53.16\%, respectively). The decreasing number of irrigation led to increasing chlorophyll under $\mathrm{RI}_{2}$ (withholding of 3 irrigation times), but with increasing withholding to 4 times, it was decreased. High moisture is not favorable for mildew and control disease (Yarwood, 1978), meanwhile chlorophyll content increased by increasing irrigation (Bhattacharya and Shukla 2002).

Table 4. Effect of water stress treatments on disease severity \%, total phenols\%, and chlorophyll\% of ten sugar beet varieties during the combined of two growing seasons 2017/2018 and 2018/2019.

\begin{tabular}{|c|c|c|c|c|c|c|c|c|c|c|c|c|}
\hline \multirow{2}{*}{ Varieties } & \multicolumn{3}{|c|}{ Disease severity\% } & \multirow{2}{*}{ 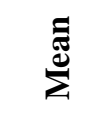 } & \multicolumn{3}{|c|}{ Total Phenols\% } & \multirow{2}{*}{$\stackrel{\Xi}{\Xi}$} & \multicolumn{3}{|c|}{ Chlorophyll \% } & \multirow{2}{*}{ 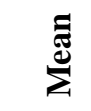 } \\
\hline & $\mathbf{I R}_{1}$ & $\mathbf{I R}_{2}$ & IR3 & & $\mathbf{I R}_{1}$ & $\mathbf{I R}_{\mathbf{2}}$ & IR3 & & $\mathbf{I R}_{1}$ & $\mathbf{I R}_{\mathbf{2}}$ & IR3 & \\
\hline Beta382 & 16.61 & 15.31 & 12.79 & 14.90 & 98.44 & 113.38 & 115.34 & 109.05 & 56.76 & 66.99 & 65.48 & 63.08 \\
\hline Gazelle & 23.78 & 20.40 & 18.96 & 21.05 & 49.37 & 53.31 & 55.32 & 52.67 & 50.69 & 61.03 & 59.57 & 57.10 \\
\hline Heba & 13.37 & 12.02 & 9.93 & 11.77 & 95.87 & 105.81 & 108.82 & 103.50 & 60.78 & 71.03 & 69.74 & 67.18 \\
\hline Nancy & 19.84 & 17.55 & 15.28 & 17.56 & 71.31 & 75.23 & 77.47 & 74.67 & 52.62 & 62.95 & 57.82 & 57.80 \\
\hline Oscarpoly & 29.38 & 25.08 & 22.51 & 25.66 & 48.03 & 51.86 & 53.87 & 51.25 & 42.85 & 53.09 & 51.61 & 49.18 \\
\hline Pleno & 15.21 & 13.91 & 11.79 & 13.64 & 97.53 & 103.36 & 105.37 & 102.09 & 58.77 & 69.01 & 66.88 & 64.89 \\
\hline Pyramide & 25.31 & 24.11 & 22.32 & 23.91 & 46.79 & 50.73 & 52.81 & 50.11 & 46.78 & 57.02 & 55.68 & 53.16 \\
\hline Rona & 21.85 & 20.55 & 18.15 & 20.18 & 66.34 & 70.28 & 76.36 & 70.99 & 48.81 & 59.05 & 63.88 & 57.25 \\
\hline Sibel & 18.11 & 16.77 & 14.33 & 16.40 & 85.89 & 89.83 & 95.91 & 90.54 & 54.78 & 65.03 & 62.69 & 60.83 \\
\hline Univers & 26.78 & 21.43 & 19.96 & 22.72 & 45.32 & 49.27 & 51.38 & 48.66 & 44.88 & 55.14 & 53.73 & 51.25 \\
\hline Mean & 21.02 & 18.71 & 16.6 & 18.78 & 70.49 & 76.31 & 79.27 & 75.35 & 51.77 & 62.03 & 60.71 & 58.17 \\
\hline \multicolumn{13}{|c|}{ L.S.D at 0.05} \\
\hline \multicolumn{3}{|c|}{ Water stress (S) } & & 1.26 & & & & 1.49 & & & & 1.61 \\
\hline \multicolumn{3}{|c|}{ Varieties (V) } & & 2.32 & & & & 1.36 & & & & 1.22 \\
\hline \multicolumn{3}{|l|}{$\mathrm{S} \times \mathrm{V}$} & & 4.64 & & & & 2.93 & & & & 2.22 \\
\hline
\end{tabular}

$\mathrm{NS}=$ Non-significant, $\mathrm{IR}_{1}$ (recommended irrigation times), $\mathrm{IR}_{2}$ (3 withholding irrigation times), and $\mathrm{IR}_{3}$ (4 withholding irrigation times) 


\section{Total phenolic compounds (g/100g. fresh weight):}

Increasing water stress significantly increased the total phenolic content as a result of decreasing powdery mildew infection (Table 4). In this respect, the highest phenol contents were recorded under $\mathrm{IR}_{3}$ (4 withholding irrigation times) compared with $\mathrm{RI}_{1}$ (recommended irrigation times). In this study, resistant varieties, Beta382 (109.05\%), Heba (103.50\%), and Pleno (102.09\%), and Sibel $(90.54 \%)$, showed the highest percentage of total phenol obtained under water stress treatments than the other susceptible varieties, Univers (48.66\%), and Pyramide (50.11\%) Oscarpoly (51.25\%). However, under normal irrigation treatment, both susceptible and resistant varieties did not show much difference in infection rate and the total phenols. Concerning the effect of interaction between water stress and varieties, it showed a significant effect on the total phenolic components. This result may be due to decrease in disease severity\% which occurred after 4 withholding irrigation times, according to Matern and Kneusal (1988) and Khan and Smith (2005), the first step of the defense mechanism in plants involves a rapid accumulation of phenols at the infection site, which act as mobilized defense system can be translocated by plants and enzymatically converted into defensive substance.

\section{Biochemical changes (Oxidative enzymes activities)}

Data in (Fig. 1) revealed that significant effects under water stress treatments and powdery mildew disease on catalase (CAT), polyphenol oxidase (PPO) and peroxidase (POD) activities in ten sugar beet varieties. Under $\mathrm{IR}_{2}$ (withholding 3 irrigation times), and under $\mathrm{IR}_{3}$ (withholding 4 irrigation times), the activities of the enzymes were significantly increased in all varieties compared to $\mathrm{IR}_{1}$ (recommended irrigation). Enzyme activity played an important role in plant disease tolerance through increasing plant defense mechanisms that are considered the main tool of varietal resistance (Takuo et al., 1993 and El-Habbak, 2003). Sugar beet varieties (Heba, Pleno, Beta382, and Sibel) were recorded the highest percentage of CAT, PPO, and POD activities) under $\mathrm{IR}_{2}$ and $\mathrm{IR}_{3}$, compared with $\mathrm{IR}_{1}$, normal irrigation. These varieties are mentioned above as the most tolerant to water stress and powdery mildew disease. The increase in enzyme activity increased the induced resistance closely associated with active resistance to powdery mildew biosynthesis, such as phytoalexins, phenols, lignins (Alkahtani et al., 2011).

According to data presented in (Fig. 1), there was a significant induction for oxidative enzymes, catalase (CAT), peroxidase (POD), and polyphenol oxidase $(\mathrm{PPO})$ in sugar beet plants under $\mathrm{IR}_{2}$ and $\mathrm{IR}_{3}$ water stress treatments. The highest increasing levels of oxidative enzymes were induced by $\mathrm{IR}_{3}$ water stress. Significant responses among the tested sugar beet varieties to water stress, as well as CAT, PPO, and POD enzymes induction rates were higher in the tolerant varieties than the susceptible varieties. According to the obtained results, reduction of disease severity values was positively correlated with the induction of CAT, POD, and PPO enzymes. These results are in line with the findings of Harrier and Watson (2004) and Avdiushko et al., (1993) indicated that many plant enzymes are involved in defense reaction against plant pathogens and drought stress, such as POD and PPO which CAT the formation of lignin and other oxidative phenols that contribute to the formation of defense barriers for reinforcing the cell structure.

\section{Effect of water stress and varieties on growth traits}

Results in Table (5) showed that water stress had a significant effect on root length, diameter, and fresh weight at $5 \%$ probability level. Root length increased by increasing withholding irrigation times, while root diameter and root fresh weight decreased. Means comparison revealed that increase water stress up to (4 withholding irrigation times), which increased root length by $14.34 \%$, however, decreased root diameter and root weight by 27.91 and $32.26 \%$, respectively, as compared with $\mathrm{IR}_{1}$, normal conditions.

Regarding the varieties effects, it was noticed that Nancy variety surpassed the other varieties in all growth traits where it recorded $29.5 \mathrm{~cm}, 11.15 \mathrm{~cm}$ and $0.92 \mathrm{~kg}$ for root length, diameter, and fresh weight traits. While the lowest mean value was obtained from Univers and Oscarpoly varieties, moreover, the interaction effect of water stress $\times$ varieties was significant on all investigated traits of sugar beet varieties. The difference among sugar beet varieties in this trait may be referred to their gene make-up effect. Similar results were obtained by (Abu-Ellail et al., 2019 and El-Mansuob and Mohamed 2014).

\section{Effect of water stress and varieties on yield traits}

Data in Table (6) showed that water stress had a significant effect on top, root and sugar yields in growing seasons. It could be noticed that growing sugar beet under $\mathrm{IR}_{3}$ (4 withholding irrigation times), scored the lowest values of top and root and sugar yields. Root yield was decreased by $22.27 \%$ under $\mathrm{IR}_{3}$, water stress compared with $\mathrm{IR}_{1}$, normal irrigation. Results showed that sugar yield under $\mathrm{IR}_{2}$ stress $(3.17$ ton/fed) was higher than under $I_{1}$ irrigation (3.04 ton/fed). 

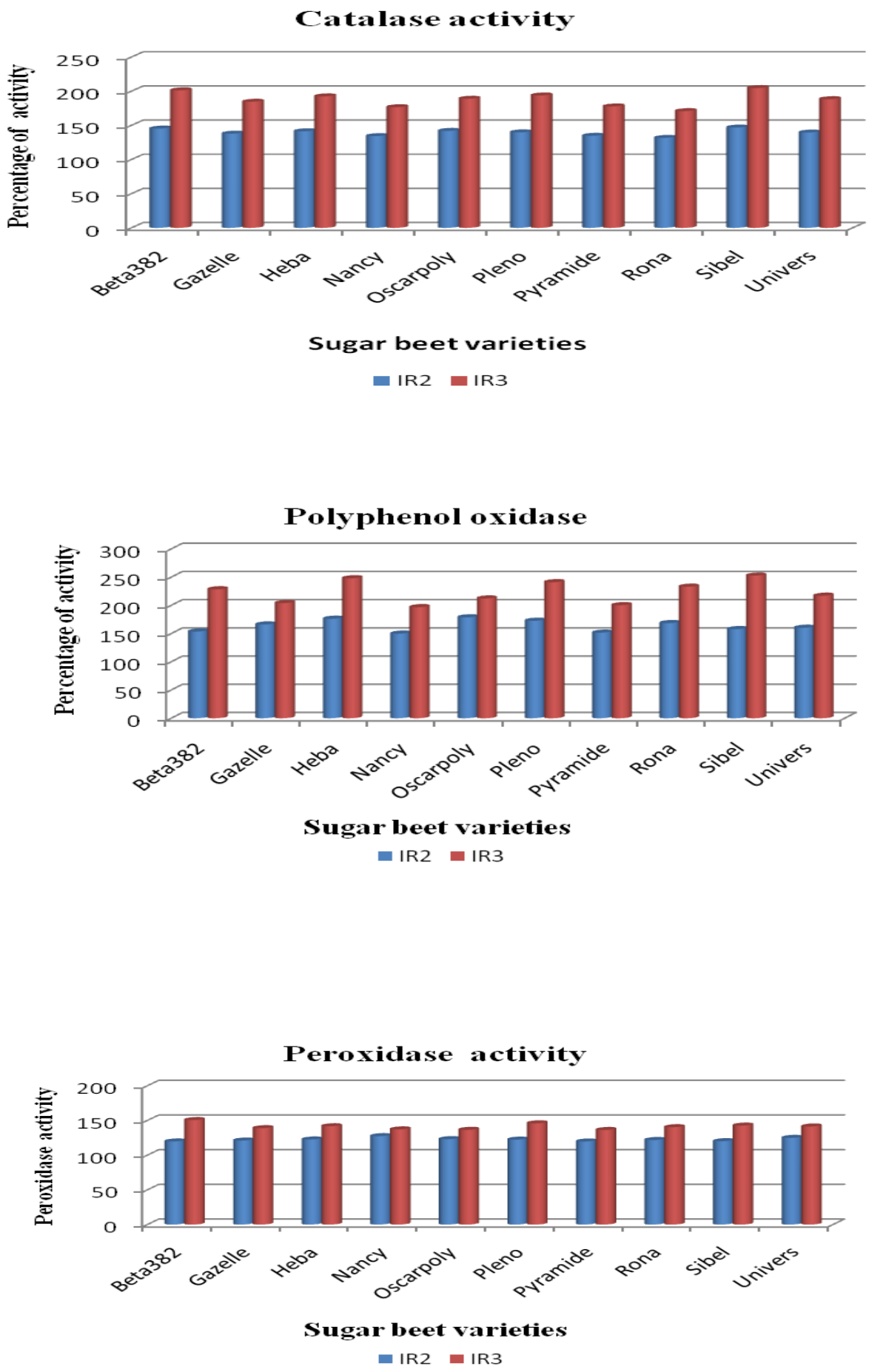

Fig. 1. Percentage of enzymes activities in ten sugar beet varieties affected by water stress treatments and powdery mildew disease 
Table 5. Effect of water stress treatments on root length, diameter, and weight of ten sugar beet varieties during the combined of two growing seasons $2017 / 2018$ and 2018/2019

\begin{tabular}{|c|c|c|c|c|c|c|c|c|c|c|c|c|}
\hline \multirow[b]{2}{*}{ Varieties } & \multicolumn{3}{|c|}{ Root length (cm) } & \multirow{2}{*}{$\stackrel{\Xi}{\Xi}$} & \multicolumn{3}{|c|}{ Root diameter $(\mathrm{cm})$} & \multirow{2}{*}{$\stackrel{\Xi}{\mathbb{E}}$} & \multicolumn{3}{|c|}{ Root weight (kg) } & \multirow{2}{*}{$\stackrel{\Xi}{\Xi}$} \\
\hline & $\mathrm{IR}_{1}$ & $\mathbf{I R}_{2}$ & IR3 & & $\mathrm{IR}_{1}$ & $\mathrm{IR}_{2}$ & IR3 & & $I_{1}$ & $\mathbf{I R}_{2}$ & IR3 & \\
\hline Beta382 & 27.23 & 29.23 & 29.65 & 28.70 & 13.08 & 10.55 & 9.74 & 11.12 & 0.96 & 0.88 & 0.68 & 0.84 \\
\hline Gazelle & 25.93 & 27.93 & 28.44 & 27.43 & 11.14 & 9.57 & 8.66 & 9.79 & 0.92 & 0.83 & 0.65 & 0.80 \\
\hline Heba & 26.23 & 28.23 & 28.75 & 27.74 & 13.41 & 9.83 & 6.69 & 9.98 & 0.86 & 0.79 & 0.58 & 0.74 \\
\hline Nancy & 28.10 & 30.10 & 30.31 & 29.50 & 12.81 & 11.24 & 9.41 & 11.15 & 1.12 & 0.93 & 0.72 & 0.92 \\
\hline Oscarpoly & 23.89 & 25.89 & 26.21 & 25.33 & 10.14 & 8.57 & 7.62 & 8.78 & 0.84 & 0.76 & 0.55 & 0.72 \\
\hline Pleno & 26.17 & 28.16 & 30.14 & 28.16 & 12.33 & 10.76 & 9.88 & 10.99 & 0.98 & 0.89 & 0.69 & 0.85 \\
\hline Pyramide & 24.85 & 26.85 & 27.28 & 26.33 & 10.78 & 9.21 & 8.27 & 9.42 & 0.88 & 0.71 & 0.59 & 0.73 \\
\hline Rona & 25.41 & 27.41 & 27.91 & 26.91 & 10.99 & 9.41 & 7.48 & 9.29 & 0.89 & 0.72 & 0.60 & 0.74 \\
\hline Sibel & 27.00 & 29.00 & 29.41 & 28.47 & 12.80 & 10.22 & 9.32 & 10.78 & 0.94 & 0.87 & 0.65 & 0.82 \\
\hline Univers & 24.51 & 26.51 & 26.76 & 25.93 & 10.39 & 8.82 & 7.91 & 9.04 & 0.92 & 0.65 & 0.54 & 0.70 \\
\hline Mean & 25.93 & 27.93 & 29.65 & 27.84 & 11.79 & 9.82 & 8.50 & 10.04 & 0.93 & 0.80 & 0.63 & 0.79 \\
\hline \multicolumn{13}{|c|}{ L.S.D at 0.05} \\
\hline \multicolumn{3}{|c|}{ Water stress (S) } & & 1.40 & & & & 0.33 & & & & 0.10 \\
\hline \multicolumn{3}{|l|}{ Varieties (V) } & & 0.97 & & & & 1.06 & & & & 0.11 \\
\hline \multicolumn{2}{|l|}{$\mathrm{S} \times \mathrm{V}$} & & & 1.71 & & & & 1.08 & & & & 0.22 \\
\hline
\end{tabular}

$\mathrm{NS}=$ Non-significant, $\mathrm{IR}_{1}$ (recommended irrigation times), IR 2 (3 withholding irrigation times), and IR 3 (4 withholding irrigation times).

Table 6. Effect of water stress treatments on top yield, root yield, and sugar yield of ten sugar beet varieties during the combined of two growing seasons 2017/2018 and 2018/2019

\begin{tabular}{|c|c|c|c|c|c|c|c|c|c|c|c|c|}
\hline \multirow{2}{*}{ Varieties } & \multicolumn{3}{|c|}{ Top yield (ton/fed) } & \multirow{2}{*}{$\stackrel{\Xi}{\tilde{\Xi}}$} & \multicolumn{3}{|c|}{ Root yield (ton/fed) } & \multirow{2}{*}{$\sum_{\overline{\mathrm{E}}}^{\overline{\mathrm{E}}}$} & \multicolumn{3}{|c|}{ Sugar yield (ton/fed) } & \multirow{2}{*}{ 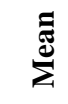 } \\
\hline & $\mathbf{I R}_{1}$ & $\mathbf{I R}_{\mathbf{2}}$ & IR3 & & $\mathbf{I R}_{1}$ & $\mathbf{I R}_{\mathbf{2}}$ & IR3 & & $\mathbf{I R}_{1}$ & $\mathbf{I R}_{\mathbf{2}}$ & IR3 & \\
\hline Beta382 & 7.34 & 8.34 & 6.13 & 7.27 & 24.78 & 23.57 & 19.14 & 22.50 & 3.24 & 3.52 & 3.09 & 3.29 \\
\hline Gazelle & 6.45 & 7.45 & 5.16 & 6.35 & 24.73 & 23.52 & 18.08 & 22.11 & 3.26 & 3.32 & 2.66 & 3.08 \\
\hline Heba & 5.71 & 6.71 & 4.38 & 5.60 & 24.18 & 23.97 & 18.45 & 22.20 & 2.66 & 3.31 & 2.64 & 2.87 \\
\hline Nancy & 6.76 & 8.76 & 6.40 & 7.31 & 25.43 & 24.22 & 19.72 & 23.12 & 3.65 & 3.66 & 3.09 & 3.46 \\
\hline Oscarpoly & 5.51 & 6.51 & 4.14 & 5.39 & 23.57 & 22.36 & 16.96 & 20.96 & 2.98 & 3.01 & 2.55 & 2.85 \\
\hline Pleno & 7.53 & 8.53 & 6.18 & 7.41 & 25.18 & 23.97 & 19.38 & 22.84 & 3.45 & 3.58 & 3.18 & 3.40 \\
\hline Pyramide & 6.04 & 7.04 & 4.68 & 5.92 & 21.35 & 20.14 & 17.66 & 19.72 & 2.60 & 2.64 & 2.55 & 2.59 \\
\hline Rona & 5.21 & 6.21 & 4.87 & 5.43 & 21.56 & 18.35 & 17.86 & 19.26 & 2.50 & 2.20 & 2.42 & 2.37 \\
\hline Sibel & 6.12 & 7.12 & 5.77 & 6.34 & 23.61 & 22.19 & 19.7 & 21.83 & 3.02 & 3.06 & 2.99 & 3.02 \\
\hline Univers & 5.09 & 6.69 & 5.37 & 5.72 & 23.96 & 23.75 & 18.31 & 22.01 & 3.13 & 3.55 & 2.70 & 3.13 \\
\hline Mean & 6.18 & 7.34 & 5.31 & 6.27 & 23.84 & 22.60 & 18.53 & 21.66 & 3.04 & 3.17 & 2.78 & 3.00 \\
\hline \multicolumn{13}{|c|}{ L.S.D at 0.05} \\
\hline \multicolumn{4}{|c|}{ Water stress (S) } & \multicolumn{4}{|l|}{0.56} & \multicolumn{4}{|l|}{0.13} & 0.21 \\
\hline \multicolumn{4}{|c|}{ Varieties (V) } & \multicolumn{4}{|l|}{0.44} & \multicolumn{4}{|l|}{1.07} & 0.28 \\
\hline \multicolumn{4}{|l|}{$\mathrm{S} \times \mathrm{V}$} & \multicolumn{4}{|l|}{1.05} & \multicolumn{4}{|l|}{1.00} & NS \\
\hline
\end{tabular}

$\mathrm{NS}=$ Non-significant, $\mathrm{RI}_{1}$ (recommended irrigation times), $\mathrm{IR}_{2}$ (3 withholding irrigation times), and $\mathrm{IR}_{3}(4$ withholding irrigation times) 
This result may be expected due to the positive effect of withholding 4 irrigation times on decreasing disease severity, meanwhile, it had a negative effect on reducing root diameter and root weight as shown previously in Tables 4 and 5, respectively. Similarly, Davidoff and Hanks (1989) reported that by decreasing the amount of water, the sugar content increased in the root. Numerous studies have shown that exposing beets to water stress leads to an increase in sugar content while causing a decrease in weight and root yield (Fotohi et al., 2008). Sugar beet varieties differed significantly in top, root and sugar yields, varieties (Pleno, Nancy, and Beta382) had the highest values under treatments, while the lowest values recorded by varieties (Rona, Pyramide and Oscarpoly). The interaction effect of water stress $x$ varieties was significant for top yield and root yield whereas sugar yield was not significantly affected by the interaction between water stress and varieties; this showed that water stress treatments and varieties under this study act independently on sugar yield; this result could be attributed to the genetic background differences among varieties. There exists a large variation in sugar beet yield and quality due to water stress tolerance among sugar beet varieties (Pigeon et al., 2006). In the conditions of high disease pressure, the reduction of root yield may exceed $22 \%$ and root sucrose content may exceed 13\% (Magyarosy, 1979; Karaoglanidis and Karadimos, 2006).

\section{Effect of water stress and varieties on quality traits}

Data illustrated in Table (7) showed that water stress had a significant effect on sucrose \%, extractable sugar\%, and sugar loss to molasses $(\mathrm{P}<0.05)$. Results showed that mean values of sucrose $\%$ and extractable sugar\% under $\mathrm{IR}_{3}$ (4 withholding irrigation times) was (17.84 and $15.03 \%$, respectively) higher than $\mathrm{IR}_{1}$ (recommended irrigation times), (15.45 and $12.76 \%$, respectively), while the sugar loss to molasses was decreased to $1.61 \%$ compared by normal irrigation $(2.53 \%)$. These results are in agreement with those obtained by Hang and Miller, (986), who reported that the concentration of sugar in water-stressed crops rises more quickly throughout the growing season, averaging between 20 and 23 percent before harvest (g sugar per $100 \mathrm{~g}$ fresh roots), compared by unstressed crops under normal irrigation conditions. Deficit water in the root led to increases in the percentage of sucrose reported by Roberts et al., (1980).

Table 7. Effect of water stress treatments on sucrose \%, extractable sugar\%, and sugar loss to molasses of ten sugar beet varieties during the combined of two growing seasons 2017/2018 and 2018/2019

\begin{tabular}{|c|c|c|c|c|c|c|c|c|c|c|c|c|}
\hline \multirow[b]{2}{*}{ Varieties } & \multicolumn{3}{|c|}{ Sucrose \% } & \multirow{2}{*}{$\sum_{\Sigma}^{\Xi}$} & \multicolumn{3}{|c|}{ Extractable sugar\% } & \multirow{2}{*}{ 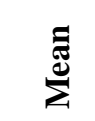 } & \multicolumn{3}{|c|}{ Sugar loss to molasses } & \multirow{2}{*}{$\underset{\Sigma}{\mathbb{E}}$} \\
\hline & $\mathbf{I R}_{1}$ & $\mathbf{I R}_{2}$ & IR3 & & $\mathbf{I R}_{1}$ & $\mathbf{I R}_{2}$ & IR3 & & $\mathbf{I R}_{1}$ & $\mathbf{I R}_{\mathbf{2}}$ & IR3 & \\
\hline Beta382 & 16.46 & 17.23 & 18.46 & 17.38 & 13.09 & 14.94 & 16.15 & 14.73 & 2.77 & 1.69 & 1.71 & 2.06 \\
\hline Gazelle & 15.71 & 16.48 & 16.91 & 16.37 & 13.19 & 14.1 & 14.73 & 14.01 & 1.92 & 1.78 & 1.58 & 1.76 \\
\hline Heba & 14.49 & 16.26 & 17.49 & 16.08 & 11.01 & 13.79 & 14.32 & 13.04 & 2.88 & 1.87 & 1.57 & 2.11 \\
\hline Nancy & 16.80 & 17.57 & 18.82 & 17.73 & 14.34 & 15.1 & 15.65 & 15.03 & 1.86 & 1.87 & 1.57 & 1.77 \\
\hline Oscarpoly & 15.20 & 15.97 & 17.29 & 16.15 & 12.64 & 13.45 & 15.05 & 13.71 & 1.96 & 1.92 & 1.64 & 1.84 \\
\hline Pleno & 15.62 & 17.41 & 18.65 & 17.23 & 13.7 & 14.92 & 16.43 & 15.02 & 2.32 & 1.89 & 1.62 & 1.94 \\
\hline Pyramide & 14.70 & 16.46 & 17.74 & 16.30 & 12.16 & 13.1 & 14.44 & 13.23 & 2.94 & 1.76 & 1.70 & 2.13 \\
\hline Rona & 14.67 & 16.46 & 17.74 & 16.29 & 11.58 & 12.01 & 13.57 & 12.39 & 2.89 & 1.85 & 1.57 & 2.10 \\
\hline Sibel & 14.20 & 17.99 & 18.32 & 16.84 & 12.79 & 13.78 & 15.19 & 13.92 & 2.81 & 1.61 & 1.53 & 1.98 \\
\hline Univers & 16.60 & 17.35 & 16.95 & 16.97 & 13.07 & 14.96 & 14.74 & 14.26 & 2.93 & 1.79 & 1.61 & 2.11 \\
\hline Mean & 15.45 & 16.92 & 17.84 & 16.73 & 12.76 & 14.02 & 15.03 & 13.93 & 2.53 & 1.80 & 1.61 & 1.98 \\
\hline \multicolumn{13}{|c|}{ L.S.D at 0.05} \\
\hline \multicolumn{3}{|c|}{ Water stress (S) } & & 0.38 & & & & 0.25 & & & & 0.36 \\
\hline \multicolumn{3}{|c|}{ Varieties (V) } & & 0.31 & & & & 0.14 & & & & 0.31 \\
\hline \multicolumn{2}{|l|}{$\mathrm{S} \times \mathrm{V}$} & & & 0.47 & & & & 0.19 & & & & 0.46 \\
\hline
\end{tabular}

$\mathrm{NS}=$ Non-significant, $\mathrm{IR}_{1}$ (recommended irrigation times), $\mathrm{IR}_{2}$ (3 withholding irrigation times), and $\mathrm{IR}_{3}$ (4 withholding irrigation times) 
Results showed that significant differences among sugar beet varieties on all juice quality traits in both seasons. Sugar beet Nancy variety recorded the highest value of sucrose \% and extractable sugar\% (17.73 and $15.03 \%$ ); while the value of the lowest of sugar lost in molasses (1.76 and $1.77 \%$ ) recorded by variety Gazelle and Nancy, respectively. The differences between studied varieties in juice quality traits may be due to the differences in growth, yield, and reaction to the surrounding environmental conditions prevailing during the formation of soluble solids in plants. The interaction effect between water stress and varieties was significant for quality traits with increasing withholding irrigation times. Sugar beet varieties i.e., Nancy follows by Pleno, and Beta382, which recorded the highest value of sucrose $\%$ extractable sugar\% compared with other varieties. Also, sugar lost to molasses\% for most varieties was reduced when withholding irrigation increased compared to normal irrigation. The results are in line with those obtained by Mahmoodi et al., (2008), who found that irrigation regimes treatments had a significant effect on sugar beet yield and quality traits. Abd El-Aal et al., (2010) and Davidoff and Hanks (1989) reported that water stress led to increased sugar content in the plant, also there were significant differences in overall yield potential and in the sucrose yield response to water stress among sugar beet genotypes (Tarkalson et al., 2014).

\section{Effects of water stress and varieties on impurities} (meq/100 g beet)

Data in Table (8) pointed out that water stress had a significant effect on $\mathrm{Na} \%$, and alpha-amino $\mathrm{N}$ in the combined of two growing seasons. It could be noticed that increasing withholding of irrigation up to 4 times increased all impurities, but the differences between treatment were not great enough to reach the five percent level of significant for $\mathrm{k} \%$ and the difference between $\mathrm{IR}_{2}$ ( 3 withholding irrigation times), and $\mathrm{IR}_{3}$ (4 withholding irrigation times). There was a significant variation among varieties for $\mathrm{Na} \%$ and $\alpha-\mathrm{N} \%$ traits. Varieties, Sibel and Nancy registered the lowest value of $\mathrm{Na} \%$ and $\alpha-\mathrm{N} \%$ compared the other varieties. Otherwise, potassium \% was insignificantly affected by withholding irrigation and varieties, the differences between studied varieties in impurities traits may be due to the variation in growth, and reaction to the surrounding environmental conditions prevailing during the formation of soluble solids in plants. Different studies showed that plants accumulate more $\alpha-\mathrm{N}$ and $\mathrm{Na}$ under stress and the impurities decrease under normal irrigation (Fotohi et al., 2008; Abu-Ellail et al., 2019; Ebrahimipak, 2010 and Noorjo and Bagaeekia, 2004).

Table 8. Effect of water stress beet varieties treatments on $\mathrm{Na} \%$, $\mathrm{K} \%$, and $\alpha$-amino $\mathrm{N} \%$ of ten sugar during the combined of two growing seasons 2017/2018 and 2018/2019

\begin{tabular}{|c|c|c|c|c|c|c|c|c|c|c|c|c|}
\hline \multirow[t]{2}{*}{ Varieties } & \multicolumn{3}{|c|}{$\mathrm{Na} \%$} & \multirow{2}{*}{$\sum_{\Sigma}^{\tilde{E}}$} & \multicolumn{3}{|c|}{ K\% } & \multirow{2}{*}{ 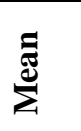 } & \multicolumn{3}{|c|}{$\alpha$-amino $\mathbf{N} \%$} & \multirow{2}{*}{$\sum_{\Sigma}^{\Xi}$} \\
\hline & $\mathbf{I R}_{1}$ & $\mathbf{I R}_{\mathbf{2}}$ & IR3 & & IR $_{1}$ & $\mathbf{I R}_{2}$ & IR3 & & $\mathbf{I R}_{1}$ & $\mathrm{IR}_{2}$ & IR3 & \\
\hline Beta382 & 2.01 & 2.48 & 2.5 & 2.33 & 2.99 & 3.67 & 3.67 & 3.45 & 2.02 & 2.52 & 2.79 & 2.44 \\
\hline Gazelle & 1.96 & 2.53 & 2.75 & 2.41 & 2.74 & 3.42 & 3.42 & 3.14 & 1.69 & 2.19 & 2.3 & 2.06 \\
\hline Heba & 1.82 & 2.39 & 2.4 & 2.20 & 2.53 & 3.20 & 3.2 & 2.93 & 1.86 & 2.35 & 2.46 & 2.22 \\
\hline Nancy & 1.74 & 2.30 & 2.35 & 2.13 & 2.91 & 3.58 & 3.58 & 3.31 & 1.68 & 2.17 & 1.95 & 1.93 \\
\hline Oscarpoly & 2.12 & 2.59 & 2.89 & 2.53 & 2.58 & 3.24 & 3.24 & 2.96 & 1.93 & 2.42 & 2.52 & 2.29 \\
\hline Pleno & 2.08 & 2.55 & 2.54 & 2.39 & 2.82 & 3.49 & 3.49 & 3.16 & 2.05 & 2.44 & 2.4 & 2.30 \\
\hline Pyramide & 2.18 & 2.66 & 3.21 & 2.68 & 3.01 & 3.56 & 3.56 & 3.33 & 1.58 & 2.07 & 2.35 & 2.00 \\
\hline Rona & 1.83 & 2.30 & 2.56 & 2.23 & 2.67 & 3.33 & 3.33 & 3.06 & 1.74 & 2.23 & 2.35 & 2.11 \\
\hline Sibel & 1.59 & 2.06 & 2.03 & 1.89 & 2.77 & 3.44 & 3.44 & 3.19 & 1.68 & 2.17 & 2.21 & 2.02 \\
\hline Univers & 2.03 & 2.50 & 2.89 & 2.47 & 2.75 & 3.42 & 3.42 & 3.15 & 1.76 & 2.25 & 2.27 & 2.09 \\
\hline Mean & 1.94 & 2.44 & 2.61 & 2.33 & 2.78 & 3.44 & 3.44 & 3.17 & 1.8 & 2.28 & 2.36 & 2.15 \\
\hline $\begin{array}{l}\text { L.S.D at } 0.05 \\
\text { Water stress }(\mathrm{S})\end{array}$ & & & & 0.34 & & & & NS & & & & 0.15 \\
\hline Varieties (V) & & & & 0.49 & & & & 0.20 & & & & 0.34 \\
\hline $\mathrm{S} \times \mathrm{V}$ & & & & 0.60 & & & & NS & & & & 0.48 \\
\hline
\end{tabular}

$\mathrm{NS}=$ Non-significant, $\mathrm{RI}_{1}$ (recommended irrigation times), $\mathrm{IR}_{2}$ (3 withholding irrigation times), and $\mathrm{IR}_{3}$ (4 withholding irrigation times) 
In this study, the $\alpha-\mathrm{N}$, as well as $\mathrm{Na}$ accumulation was lower under normal irrigation times than water stress treatments. The interaction effect between water stress and varieties was significant for $\mathrm{Na} \%, \mathrm{~K} \%$, and $\alpha$-amino $\mathrm{N} \%$ during the combined two growing seasons $2017 / 2018$ and $2018 / 2019$. However, by growing sugar beet plant under $\mathrm{IR}_{1}$ (recommended irrigation times), results demonstrated that Sibel variety recorded the lowest value of $\mathrm{Na} \%$ (1.59), and the lowest value of $\alpha$ amino $\mathrm{N} \%(1.68 \%)$ under $\mathrm{IR}_{1}$ treatment, in addition Heba variety recorded the lowest value of $K \%$ (2.53\%). These showed that water stress treatments and varieties act dependently on the previous studied characters (Table 8). Similar results were reported by Abd El-All and Makhlouf (2017) and Hosseinpour et al., (2006), who found that impurities\% decreased by increased water stress in the first and second seasons, respectively.

Identification of stress tolerant varieties by using selection indexes

\section{Drought susceptibility index (DSI)}

According to the drought susceptibility index (Fig. 2), Pleno variety followed by Sibel and Rona had the lowest (DSI) values less than unit, which were considered as varieties with low drought susceptibility and high root and sugar yields in stress and non-stress conditions, whereas Oscarpoly variety followed by Gazelle and Univers varieties with DSI values higher than the unit can be identified as high drought sensitivity and low root and sugar yields. It is concluded that the effectiveness of selection indices depends on the stress severity supporting the idea that only under moderate stress conditions, potential yield greatly influences yield under stress (Blum, 1997). Drought susceptibility index (DSI) is an effective identifier for varieties with high yield in both stressed and nonstressed environments (Sadeghian et al., 2000 and Tarkalson et al., 2014).

\section{Stress tolerance index (STI)}

Based on the stress tolerance index for root yield (Fig. 3), all varieties had STI high than the unit was considered to be tolerant genotypes and high root yield under non-stress and less reduction under stress conditions. However, there are varied significantly among varieties in the STI for sugar yield, Nancy variety followed by Beta382 and Sibel with the highest values were considered to be tolerant genotypes, whereas the Oscarpoly variety followed by Rona with the lowest STI were intolerant, results indicated that varsities with high STI usually have a high difference in yield in two different conditions. These results are in line with (Sadeghian et al., 1999; Rover and Buttner, 1999) who indicated that STI was the only index, which had a positive correlation with mean sugar yield under both limited and continuous stress, as well as adequate water conditions. This confirms the advantage of STI as selection criteria for identifying high yielding, stresstolerant sugar beet varieties.

Drought susceptibility index (DSI)

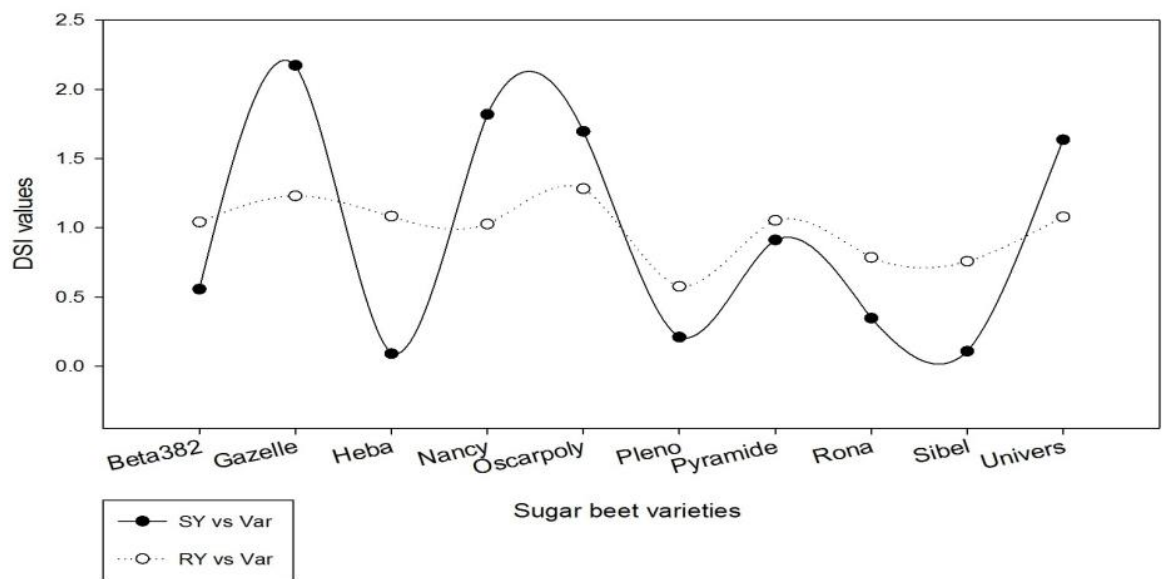

Fig. 2. Values of drought susceptibility index (DSI) for root yield (RY) and sugar yield (SY) under non-stress and stress conditions (over two years). 


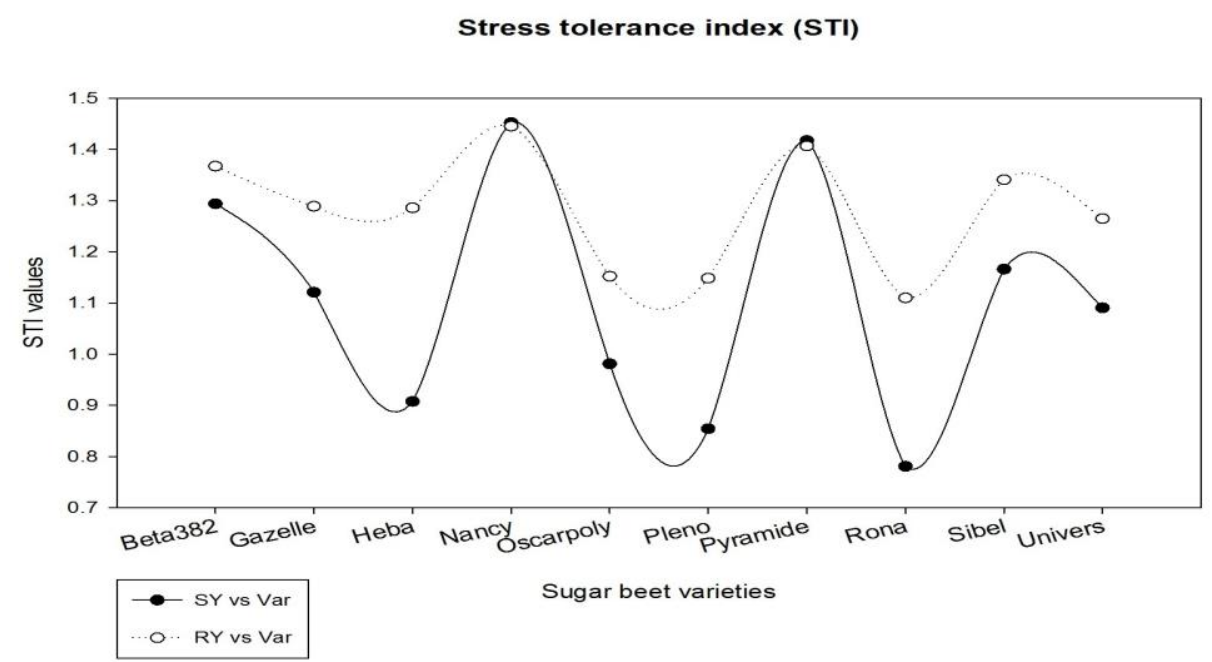

Fig. 3. Values of stress tolerance index (DSI) for root yield (RY) and sugar yield (SY) under non-stress and stress conditions (over two years).

\section{Geometric mean productivity (GMP)}

Results in Figure (4) indicted that geometric mean productivity (GMP) varied significant aomg sugar beet varieties for root and sugar yield. In general, similar ranks for the varieties were observed by GMP and STI indices, which suggested that these two indices were equal for selecting genotypes. Selecting high yielding varieties based on GMP index would not necessarily produce varieties that were productive in diverse environments. The difference between the highest and lowest root yielding variety was about 2.76 and 4.08 tons /fed in $\mathrm{IR}_{3}$, stress, and $\mathrm{IR}_{1}$, non-stress conditions, respectively (Table 6). Results suggest that indirect selection in a water stress environment would improve yield in a water stress environment better than a selection from a non-water stress environment. Selecting high yielding varieties' based on DSI, or STI indexes would not necessarily identify varieties that produce a high yield, indicated that GMP can identify genotypes with high yield potential under both stress and well-watered conditions. The index GMP exhibited a strong correlation with YS and YP, therefore, it can discriminate drought-tolerant genotypes with high white sugar yield in under stress and non-stress conditions (Hesadi et al., 2015).

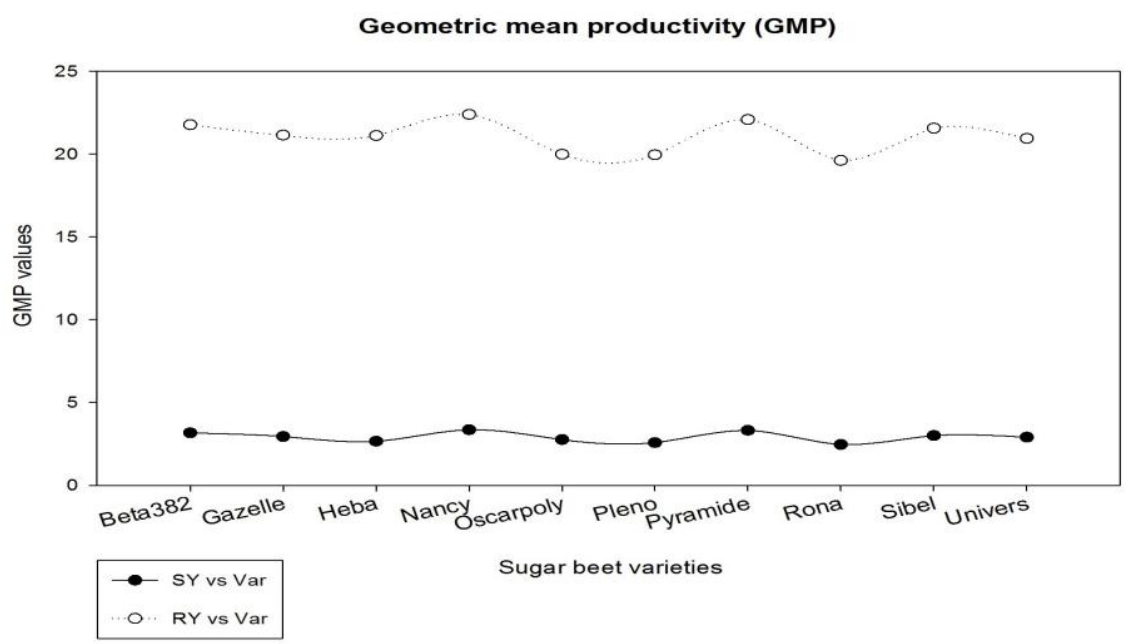

Fig. 4. Values of geometric mean productivity (GMP) for root yield (RY) and sugar yield (SY) under nonstress and stress conditions (over two years). 


\section{CONCLUSION}

The present study concluded that powdery mildew disease in sugar beet plant was significantly reduced by applied the tested water stress treatments i.e. four and three withholding irrigation times compared to the normal irrigation. Three withholding irrigation times was the best treatment for reducing powdery mildew disease and gave the highest content of phenols and antioxidant enzymes. Sugar beet varieties i.e. Heba, Beta382, and Sibel recorded the highest value of oxidative enzyme activity, which is an important role defense in that are considered the main tool of varietal resistance. Sugar beet breeders should take into account the stress severity of the environment when choosing an index. DSI, STI, and GMP were able to identify varieties producing high yield in stress and non-stress conditions.

\section{REFERANCES}

A.O.A.C. 2005. Association of Official Analytical Chemists. Official Methods of analysis, 16th Ed. International Washington, D.C. USA.

Abd El-Aal, A.M., A.I. Nafie and Ranya M. Abdel Aziz .2010. Response of some sugar beet genotypes to nitrogen fertilization under newly reclaimed land conditions. Egypt. J. Appl. Sci., 25 (6B) 194-208.

Abd El-All, A. E. A. and B. S. I. Makhlouf .2017. Response of sugar beet to continuous deficit irrigation and foliar application of some micronutrients under sandy soil conditions. J. Soil Sci. and Agric. Eng., Mansoura Univ., 8 (12): $749-760$.

Abu-El-Lail F.F.B., K.A. Hamam, K.A. Kheiralla and M.Z. El-Hifny.2 016. Evaluation of twenty barley genotypes for drought tolerance under sandy clay soil. Egypt. J. Agron. 38(2): 173-187.

Abu-Ellail F.F.B., K.A. Sadek and H.M.Y. El-Bakary. 2019. Broad-sense heritability and performance of ten sugar beet varieties for growth, yield and juice quality under different soil salinity levels. Bull. Fac. Agric., Cairo Univ., 70:327339.

Alkahtani, M., S.A. Omer, M.A. El- Naggar, M.A. Eman and M.A. Mahmoud, 2011. Pathogenesisrelated protein and phytoalexin induction against cucumber powdery mildew by elicitors. Int. J. Plant Pathol., 2: 63-71.

Asher, M., and A. Dewar. 2001. Pests and diseases in sugar beet. British Sugar Beet Review, 69: 21-26.

Avdiushko, S. A., X. S. Ye and J. Kuc .1993. Detection of several enzmetic activities in leaf prints of cucumber plants. Physiological and Molecular Plant Pathology, 42: 441-454.
Barry, J. J., N.K. Zidack, J. Ansley, B. Larson, J.L.A. Eckhoff and J. Bergman .2000. Integrated management of Cercospora leaf spot. Sugarbeet Research and Education Board (SBAR funds), Syngenta, Bayer, BASF, Griffin, and Sipcam Agro-USA.

Basati, J., M.Sheikholeslami, A.Jalilian, M.R. Jahadakbar and F. Hamdi .2015. Effects of sprinkler and furrow irrigation systems on powdery mildew disease severity in sugar beet. J. Sugar Beet, 30(2): 73-79.

Bhattacharya A. and P. Shukla .2002. Effect of environmental factors on powdery mildew severity in field pea under irrigated and rainfed conditions. Indian J. Agric. Res., 36 (3): $149-155$.

Blum, A. (1997) Crop responses to drought and the interpretation of adaptation. In: "Drought Tolerance in Higher Plants: Genetical, Physiological and Molecular Biological Analysis"; Belhassen, E. (Ed.), Springer, Dordrecht, Netherlands. pp. 57-70.

Brown, J.D. and O. Lilliand .1964. Rapid determination of potassium and sodium in plant material and soil extracts by Flamphotometry. Proc. Amer. Soc. Hort. Sci., 48: $341-$ 346.

Davidoff, B., and RJ. Hanks .1989. Sugar beet production an influenced by limited irrigation. J. Irrig. Scie. 10:1-17.

Devillers, P. 1988. Prevsion du sucre melasse. Scurries francases .129: 190-200. (C.F. the sugar beet book).

Dexter, S.T., M. Frankes and F. W. Snyder .1967. A rapid of determining extractable white sugar as may be applied to the evaluation of agronomic practices and grower deliveries in the sugar beet industry. J. Am., Soc., Sugar Beet Technol. 14: 433 - 454.

Draycott, A. P. 2006. Sugar Beet, Powdery Mildew, Blackwell Publishing Professional, 2121 State Avenue, Ames, Iowa 50014-8300, USA, pp291.

Ebrahimipak, N.A. 2010. Reaction of sugar beet yield to low irrigation in different step of sugar beet growth. J. Sugar Beet, 26 (1):67-79.

El-Habbak, M. H. 2003. Induction of resistance to powdery mildew disease of Squash plants. M.Sc. thesis, Fac. of Agric., Mosh. Zagazig. Univ., Benha Branch.

El-Mansoub, M.M.A. and H. Y. Mohamed .2014. Effect of sowing dates and phosphorus on root rot and quality of some sugar beet varieties. J. Plant Production, Mansoura Univ., 5 (5): 745-764.

Fernandez, G.C.J .1993. Effective selection criteria for assessing stress tolerance. Proceedings of the International Symposium on Adaptation of Vegetables and Other Food Crops in Temperature and Water. Stress Tolerance. Asian Vegetable Research and Development Centre, Taiwan, 257-270 p.

Fischer, R.A and R. Maurer.1978. Drought resistance in spring wheat cultivars. I. Grain yield response. Austr J Agricult Res 29:897-907. 
Fotohi, K., J. Ahmadasi , A. Noorjo, A. Pedram and A. Khorshid .2008. Irrigation of management based on humidity of soil in different step of growth in sugar beet in Miandoab. J. Sugar Beet. 24(1):43-60. (In Persian, abstract in English).

Francis, S. 2002. Sugar-beet powdery mildew (Erysiphe betae). Mol Plant Pathol., 3 (3):119-124.

Gado, E.A.M. 2013. Impact of treatment with some plant extracts and fungicides on sugar beet powdery mildew and yield components. Australian J. of Basic and Applied Sci., 7(1): 468-472.

Gary, S.,R. Viviana and K. Mohamed. 2011. Sensitivity of Cercospora beticola to foliar fingicides in 2011. Dep. of Plant Path., North Dakota State Univ., Fargo, ND 58108 USA.

Gomez, K.A. and A.A. Gomez.1984. Statistical Procedures for Agriculture Research. John Wiley and Sons. Inc. New York.

Hammerschmidt R., E. M. Nuckles and J. Kuc .1982. Association of enhanced peroxidase activity with induced systemic resistance of cucumber to Colletotrichum lagenarium. Physiology and Plant Pathology, 20:73-82

Hang, A.N., D.E. Miller .1986. Yield and physiological responses of potatoes to deficit, high frequency sprinkler irrigation. Agron. J. 78: 436-440.

Harrier, L. A. and C.A. Watson .2004. The potential role of arbuscular mycorrhizal (AM) fungi in the bioprotection of plants against soil-borne pathogens in organic and/or other sustainable farming systems. Pest Manag Sci 60:149-157.

Hesadi P., D. F. Taleghani, A. Shiranirad, J. Daneshian and A. Jaliliyan. 2015 . Selection for drought tolerance in sugar beet genotypes (Beta vulgaris L.) Biological Forum-An International J. 7(1): 1189-1204.

Hills, F.J., L. Chiarappa and S. Geng .1980. Powdery mildew of sugar beet: Disease and crop loss assessment. Phytopathology. 70: 680- 682.

Hosseinpour, M., A. Sorooshzadeh, M. Aghaalikhani, M. Khoramian, D.F. Taleghani (2006). Evaluation of quantity and quality of sugar beet under drip and furrow irrigation methods in north of Khuzestan. J. Sugar Beet., 22(1): 3957.

Karaoglanidis, G.S. and D.A. Karadimos, 2006. Control of sugar beet powdery mildew with Strobilurin fungicides, Proc. Nat. Sci, Matica Srpska Novi Sad, 110: 133-139.

Khan, M.F.R. and L.J.,Smith .2005. Evaiuating fungicides for controlling cercospora leaf spot on sugar beet. Crop protection, 24: 79-86.

Magyarosy, A.C., P. Schurmann and B.B. Buchanan, 1976. Effect of powdery mildew on photosynthesis by leaves and chloroplasts of sugar beets. Plant Physiol., 57: 486489.

Mahmoodi, R., H. Maralian, A. Aghabarati .2008. Effects of limited irrigation on root yield and quality of Sugar beet (Beta vulgaris L.). African. J. Biol. 7(24): 4475-4478.

Matern, U. and R.E. Kneusal.1988. Phenolic compounds in disease resistance. Physiopathology 68: 153-170.
Maxweell, D.P. and D.F. Bateman.1967. Changes in the activities of some oxidases in extracts of Rhizoctonia infected bean hypocotyles in relation to lesion maturation. Phytopathology 57:132-136.

Mayer, A.M., Harel, E. and, R. B., Shaul 1965. Assay of catechol oxidase a critical comparison of methods. Phytochemistry, 5: 783-789.

Mohamdian, R. 2010. Determine indicators, physiological affecting the selection of drought tolerant hybrids of sugar beet. PhD thesis, University of Tabriz.

Neher, O.T. and J. J. Gallian .2013. Powdery mildew on sugar beet. A Pacific Northwest Extension Publication University of Idaho, pp.1-5, available at https://www.extension.uidaho.edu/publishing/pdf/PNW/P NW643.pdf

Noorjo, A. and M. Bagaeekia 2004. Effect of cut irrigation in different step of sugar beet growth on quantity and quality of sugar beet. J. of Sugar Beet. 20(1):27-38. (In Persian, abstract in English)

Paulus, A.O., O.A. Harvey, J. Nelson and V. Meek. 2001. Fungicides and timing for control of sugar beet powdery mildew. Plant Disease Reporter. 59: 516-517.

Pigeon, J. D., E. S. Ober, A. Qi, C. J. A. Clark, A. Royal, and K. W. Jaggard. 2006. Using multi-environment sugar beet variety trials to screen for drought tolerance. Field Crop Res. 95:268-279.

Pivonia S., R. Cohen, S. Cohen, J. Kigel, R. Levita and J. Katan. 2004. Effect of irrigation regimes on disease expression in melon plants infected with Monosporascus cannonballus . Euro. J. Plant Pathology 110: 155-161.

Roberts, S., J.E. Middleton, A.W. Richards, W.H. Weaver, L.F. Hall .1980. Sugar beet production under center pivot irrigation with different rates of nitrogen. Bull. College. Agric. Res. Cent., Washington State Univ. No 884:5pp.

Rotem, J. and J. Palti. 1969. Irrigation and plant diseases. Annu. Rev. Phytopathol. 7: 267-288.

Rover A. and G. Buttner. 1999. Influence of drought stress on the internal quality of sugar beet. 62th IIRE Congress. Sevilla 7-10 June.

Sadeghian, S.Y., H. Fasli, M. Parvizi, D. Almani, Fatollah Taleghani, and R. Mohammadian. 1999. Drought tolerance screening for sugar beet improvement. A paper presented in the first International Congress on Sugar and Integrated Industries "Present and Future", Feb. 15th 18th, Luxur, Egypt.

Sadeghian, S.Y., H. Fazli, R. Mohammadian, D. F. Taleghani and M. Mesbah .2000.Genetic Variation for drought stress in sugar beet. J. Sugar Beet Res. 37(3): 55-77.

Singleton, V.L., R. Orthofer and R.M. L. Raventos .1999. Analysis of total phenols and other oxidation substrates and antioxidants by means of Folin-Ciocalteau reagent. Methods Enzymol. 299:152-178.

Srivastava, S.N.2004. Disease Management of Fruits and Vegetables, Management of Sugar beet Diseases, Kluwer Academic Publishers. Printed in the Netherlands. Vol. 1. Fruit and Vegetable Diseases (ed. K.G. Mukerji), 307-355. 
Farrag F.B. Abu-Ellail ${ }^{*}$ and Mohamed M. A. El-Mansoub: Impact of Water Stress on Growth, Productivity and Powdery ...

Takuo, S., S. Tatsuji, H.Johan and V.Erick .1993. Pectin, Pectinase and Protopectinase: protection, properties and applications. Adv. Appl. Microbiol., 39: 213-294.

Tarkalson, D. D., I. Eujayl, W. Beyer, and B. A. King .2014. Drought tolerance selection of sugarbeet hybrids. J. Sugar Beet Res. 51 (1 \& 2):14-30.

Uddling, J., J. Gelang-Alfredsson, K. Piikki , H. Pleijel .2007. Evaluating the relationship between leaf chlorophyll concentration and SPAD-502 chlorophyll meter readings. Photosynth Res. 91:37-46. DOI 10.1007/s11120-0069077-5.
Waller, R.A. and D.B. Duncan .1969. A bays rule for the symmetric multiple comparison problem. Amer. State. Assoc. J. Des., 1458-1503.

Whitney, E.D., R.T. Lewellen and I.O. Skoyen, 1983. Reaction of sugar beet to powdery mildew: Genetic variation, association among testing procedures, and results of resistance breeding. Phytopathology, 73: 182185.

Yarwood, C.E. 1978. History and taxonomy of powdery mildews. In: The Powdery Mildews (Spencer, D.M., Ed.). London: Academic Press, Pp.1-38.

\section{الملخص العربي}

\section{تأثير الإجهاد المائي على النمو والإنتاجية ومرض البياض الاقيقي لعشرة أصناف من بنجر السكر}

$$
\text { فراج فرغل برعى أبو الليل، محمد محمد عبد العاطى المنسوب }
$$

(منع 4 ريات) محصولاً أقل (2.78 و 18.53 طن/ فدان) من معاملة الإجهاد المائى (منع 3 ريات) (3.17 و22.60 طن/فدان). ونتيجة لذلك، أدى منع 3 فترات من الري إلى زيادة نسبة السكر وقلة تراكم الأمونيا والنيتروجين والصوديوم في الجذر، مقارنة بـ منع 4 ريات. لقد سجل الصنف (هبة) أقل نسبة شدة إصابة بالمرض (11.77\%) مع محصول جذري مناسب (22.20 طن/فدان). سجلت أصناف بنجر السكر (هبة وبيتا 382 وسييل) أعلى قيمة للأنزيمات المؤكسة (الكاتالاز، البيروكسيديز، بوليفينول أوكسيديز)،

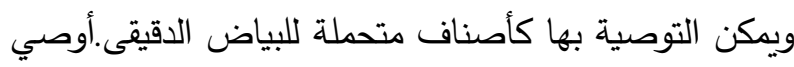
بتخطي رية واحدة أو أكثر لتقليل مرض البياض الدقيقي.وفقًا

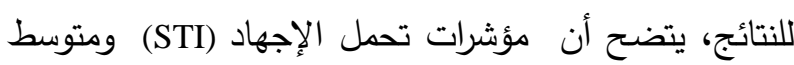
الإنتاجية الهندسية (GMP) مؤشرات اختيار مناسبة لتحديد أصناف بنجر السكر المتحملة للإجهاد المائي. يجب على ملى الإسلى المربين التركيز على أداء الأصناف ذات المحصول العالي والسكر القابل للإِ ستخلاص في البيئات المتتوعة. الكلمات المفتاحية: بنجر السكر، البياض الدقيقي، شدة المرض، الإجهاد المائي، مؤشر تحمل الإجهاد.
البياض الدقيقي هو مرض فطري يسبب انخفاضًا في إنتاجية الجذور والسكر في مناطق زراعة بنجر السكر في مصر • تهدف هذه الدراسة إلى تحديد تأثير ثلاثة معاملات من الإجهاد المائى وهى كالأتى IR Iالري الرهي الموصى به)،

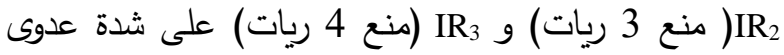
مرض البياض الدقيقي ومكونات المحصول لعشرة أصناف من بنجر السكر. كان التصميم التجريبي عبارة عن قطع منشقة مرة واحدة بثلاث مكررات في محافظة الفيوم، (29

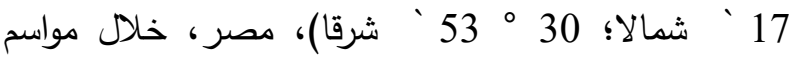
2018/2017 و2019/2018. أوضحت النتائج أن شدة المرض اختلفت بشكل كبير تحت معاملات الإجهاد المائى الثلاثة حيث بلغت 21.02، 18.71 و16.60\% على التوالي. وفي الوقت نفسه، فإن حجب 4 ريات كان أكثر فعالية في السيطرة على مرض البياض الدقيقي ولكن نتج عنه إنخفاض في المحصول ومكوناتة. سجلت الأصناف، مثل ( Heba ،

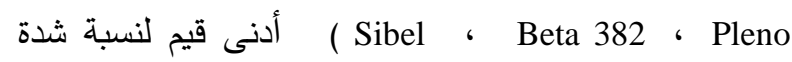
المرض (11.77 و13.64 و14.90 و16.40\% على التوالي). كان لمنع الرى تأثير معنوي (P (P) Pلى محصول السكر والجذور بحيث سجلت معاملة الإجهاد المائى 